\title{
DNA-barcoding clarifies species definitions of Finnish Apatania (Trichoptera: Apataniidae)
}

\author{
Juha Salokannnel, Markus J. Rantala \& Niklas Wahlberg
}

\begin{abstract}
Salokannel, J., Rantala, M. J. \& Wahlberg, N. 2010: DNA-barcoding clarifies species definitions of Finnish Apatania (Trichoptera: Apataniidae). — Entomol. Fennica 21: 1-11.
\end{abstract}

\begin{abstract}
All the known 8 Finnish Apatania Kolenati species were analysed using the DNA barcoding method. The Finnish species were grouped in four clades; A. zonella (Zetterstedt, 1840) group sensu lato, A. stigmatella (Zetterstedt, 1840), A. wallengreni (McLachlan, 1871) and A. muliebris McLachlan, 1866. The $A$. zonella group sensu lato consists of $A$. zonella, A. dalecarlica (Forsslund, 1942), A. forsslundi Tobias, 1981, A. auricula (Forsslund, 1930) and A. hispida (Forsslund, 1930). The DNA barcoding results support keeping all these 8 taxa as separate, good species. The main distribution and larval environment of $A$. zonella and $A$. dalecarlica in Finland were clarified. In addition to the 8 species, a morphologically distinct taxon close to A. hispida was included in the analysis and is discussed. Photographs of the genitalia of all taxa are provided as well as a key for identifying the taxa.
\end{abstract}

J. Salokannel, Siikinkatu 13, FI-33710 Tampere, Finland; E-mail: juha. salokannel@nic.fi

M. J. Rantala, Department of Biology, University of Turku, FI-20014 Turku, Finland;E-mail:markus.rantala@utu.fi

N. Wahlberg, Department of Biology, Laboratory of Genetics, University of Turku, FI-20014 Turku, Finland; E-mail: niklas.wahlberg@utu.fi

Received 3 December 2009, accepted 8 January 2010

\section{Introduction}

The family Apataniidae (Wallengren 1886) is a northern and montane group, which is known from North America, Europe and Asia, consisting of about 200 species (Holzenthal et al. 2007). The genus Apatania Kolenati is the only genus representing the family in Europe. The genus comprises worldwide about 100 species (Holzenthal et al. 2007), of which about 30 are found in Europe (Malicky 2005), and 8 in Finland (Salokannel et al. 2004, Ilmonen \& Rinne 2005), the exact numbers depending on whether some of the taxa are treated as species or subspecies.
Apataniids are mainly found in cool running waters (Holzenthal et al. 2007), in northern latitudes, as well as in lakes, larger rivers (Nielsen 1943, Solem 1985) and even in brackish water (Carlsson 1982, Gullefors 2005). All apataniid larvae are thought to feed on periphyton, which grows on stony surfaces in aquatic environments (Holzenthal et al. 2007). Apataniid larvae build a case of small bricks of sand or fine gravel. The life cycle varies from one year to two or even more in cold environments (Solem 1985).

Parthenogenesis is known among some Apatania species (Malicky 2005). Among Finnish species, A. wallengreni and A. stigmatella 
have equal shares of males and females. There are no males known of $A$. hispida, A. muliebris and $A$. forsslundi (Malicky 2004), thus they are considered to be fully parthenogenetic. In populations of A. zonella and A. dalecarlica females are dominating (Solem 1985, Malicky 2005). In Finnish populations, so far only one male of $A$. auricula has been found among some hundreds of females.

Identifying species of Apatania is challenging. The microscopic morphological characters of some species of Apatania females are relatively similar between putative sister species, and the characters may vary relatively much between specimens within one species (Solem 1985). At the same time, the majority or all of the samples are females in many species due to parthenogenecy.

The concept of identification through DNA barcoding is gaining acceptance (Hebert et al. 2003, Silva Brandão et al. 2009), although there are still issues to be addressed (e.g. Wahlberg et al. 2003, 2009, Elias et al. 2007). It is acknowledged currently that DNA barcoding is one process in the taxonomic tool box and that by using all possible information, such as morphology, behaviour and ecology, one arrives at the most robust taxonomic hypothesis (Silva Brandão et al. 2009). Finnish Apatania species have been studied intensively using traditional morphological and ecological approaches, but problems remain in species delimitations, e.g. whether the taxa $A$. dalecarlica and A. zonella should be considered separate species or variations of a single species. In this study we applied the DNA barcoding concept to Finnish Apatania species to test the current species delimitations. Many Apatania species can be used as indicator species of clean, natural ground water springs, and using DNA barcodes could simplify identification, including also immature stages. Some Apatania species may be threatened due to sporadic and very limited suitable larval habitats and they would be worth monitoring.

\section{Material and methods}

The material was collected from different parts of Finland during 2002-2007, the adults by butterfly net, Malaise traps or light traps and the larvae with the kick-net sampling method. The majority of the sampling sites were cold spring or mountain brooks, but also several lakes, large subarctic ponds and subarctic rivers were studied. All the material was preserved in $96 \%$ ethanol, although part of the material was first stored in lower concentration ethanol or in a freezer. In total 83 individuals were sampled from all Finnish species (3-24 individuals per species, Table 1). The taxa A. dalecarlica and A. zonella were sampled intensively to test whether DNA-barcoding supports keeping them as two separate taxa, which is suggested by male genitalia.

Total genomic DNA was extracted from two legs using QIAgen's DNEasy extraction kit. The DNA-barcode was amplified and sequenced from all specimens using the standard primers LCO 5' GGT CAA CAA ATC ATA AAG ATA TTG G 3' and HCO 5' TAA ACT TCA GGG TGA CCA AAA AAT CA 3' (Folmer et al 1994). All PCRs were performed in a $20 \mu 1$ reaction volume using $1 \mu \mathrm{l}$ of DNA extract. The cycling profile was $95^{\circ} \mathrm{C}$ for $5 \mathrm{~min}, 40$ cycles of $94^{\circ} \mathrm{C}$ for 30 sec, $50^{\circ} \mathrm{C}$ for $30 \mathrm{sec}, 72^{\circ} \mathrm{C}$ for $1 \mathrm{~min} 30 \mathrm{sec}$ and a final extension period of $72^{\circ} \mathrm{C}$ for $10 \mathrm{~min}$. Sequencing was performed with an ABI 3130x1. Sequences have been checked and aligned by eye using the software BioEdit (Hall 1999).

The resulting sequences were placed in the Barcode of Life Database (BOLD; http://www. barcodinglife.org/), where a project (TRIFI) was created. The sequences were analysed in BOLD using the standard neighbour-joining (NJ) method with pairwise distances correct using the K2P model. Sequence divergences were calculated based on $\mathrm{K} 2 \mathrm{P}$ distances using the program MEGA 4 (Kumar et al 2004).

The data were also analysed phylogenetically using maximum parsimony and Bayesian methods. For these analyses, the data were pruned to only unique haplotypes. Most parsimonious cladograms were searched for from the equally weighted and unordered data matrix using a heuristic search algorithm of NONA 2.0 (Goloboff 1998). The heuristic searches were conducted with 10-1,000 random addition replicates using tree bisection-reconnection (TBR) branch swapping with up to twenty trees held during each step. Trees were drawn with the aid of Winclada (Nixon 2002). Clade support was evaluated using 
Table 1. List of Apatania and Limnephilus specimens sampled for DNA. The biogeographical provinces of Finland follow Kullberg et al (2002: Fig. 2).

\begin{tabular}{|c|c|c|c|c|c|c|c|}
\hline Species & $\begin{array}{l}\text { Province } \\
\text { Region }\end{array}$ & $\begin{array}{l}\text { BOLD } \\
\text { code }\end{array}$ & $\begin{array}{r}\text { Voucher } \\
\text { code }\end{array}$ & Species & $\begin{array}{l}\text { Province } \\
\text { Region }\end{array}$ & $\begin{array}{l}\text { BOLD } \\
\text { code }\end{array}$ & $\begin{array}{r}\text { Voucher } \\
\text { code }\end{array}$ \\
\hline A. auricula & Ta Pälkäne & TRIFI009-08 & ME009 & A. dalecarlica & Ks Salla & TRIFI104-08 & ME110 \\
\hline A. auricula & Ta Pälkäne & TRIFI010-08 & ME010 & A. forsslundi & Li Utsjoki & TRIFI019-08 & ME019 \\
\hline A. auricula & Ta Pälkäne & TRIFI011-08 & ME011 & A. forsslundi & Li Inari & TRIFI030-08 & ME030 \\
\hline A. auricula & Ta Pälkäne & TRIFI012-08 & ME012 & A. forss/undi & Lk Kittilä & TRIFI031-08 & ME031 \\
\hline A. auricula & Ta Pälkäne & TRIFI013-08 & ME013 & A. forss/undi & L & 08 & $=034$ \\
\hline A. auricula & Ta Valkeakoski & TRIFI014-08 & ME014 & A. hispida & $\mathrm{Li} \mathrm{Ut}$ & RIFI045-08 & ME045 \\
\hline A. auricula & Ta Valkeakoski & TRIFI015-08 & ME015 & A. hi & & & ME046 \\
\hline A. auricula & Ta Valkeakoski & TRIFI016-08 & ME016 & A. hispida & Li Utsjoki & TRIFI047-08 & ME047 \\
\hline A. auricula & Ta Nokia & TRIFI017-08 & ME017 & A. hispida & & TRIFI048-08 & ME048 \\
\hline A. auricula & Tb Viitas & TRIFIC & ME105 & da & & & ME049 \\
\hline A. dalecarlica & Ks Salla & TRIFIO & ME001 & & & & ME050 \\
\hline A. dalecarlica & Ok Paltamo & TRIFI004-08 & ME004 & da & & & ME051 \\
\hline A. dalecarlica & Ks Salla & TRIFI005-08 & ME005 & A. hispida & & TRIFI052-08 & ME052 \\
\hline A. dalecarlica & Sa Rautjärvi & TRIFIC & & A. nr. hispida & & & ME040 \\
\hline A. dalecarlica & Li Uts & TRIF & ME020 & ida & & & ME042 \\
\hline A. dalecarlica & Iillt & & 21 & & & & E043 \\
\hline A. dalecarlica & Li Uts & TRIFI022-08 & ME022 & A. $\mathrm{r}$ & Lk & 08 & ME044 \\
\hline A. dalecarlica & Li Utsjoki & TRIFI023-08 & ME023 & A. muliebris & & TRIFI053-08 & ME053 \\
\hline rlica & $\mathrm{LiU}$ & 88 & & & & & ME054 \\
\hline arlica & $\mathrm{LiU}$ & & ME025 & ris & tek & & ME078 \\
\hline A. dale & Li In & 08 & $\mathrm{M}$ & ella & & & ME055 \\
\hline A. dalecarlica & Li Inari & TRIFI027-08 & ME027 & atella & Li Utsjoki & TRIFI056-08 & ME056 \\
\hline A. dalecarlica & Li Inari & TRIFI028-08 & ME028 & A. stigmatella & Li Utsjoki & TRIFI057-08 & ME057 \\
\hline & Iiln & & & & $\mathrm{T}$ & & ME058 \\
\hline A. dalecarlica & Lk Ki & & 32 & & & & ME059 \\
\hline A. dalecarlica & Lk Kit & TRIFI & ME & A. stigmatella & Ta Valkeakoski & TRIFI060-08 & ME060 \\
\hline A. dalecarlica & St Jän & TRIFI & ME035 & engreni & Le Enontekiö & TRIFI062-08 & ME062 \\
\hline A. dalecarlica & St Jämijärvi & TRIFI036-08 & ME036 & A. wallengreni & Le Enontekiö & TRIFI063-08 & ME063 \\
\hline rlica & $T_{1}$ & & & & Le & -08 & ME065 \\
\hline ecarlica & $\mathrm{Ta} \mathrm{Hol}$ & & ME038 & & Li Uts & TRIFI & ME067 \\
\hline A. dalecarlica & Ta Hollola & TRIFI039-08 & $\mathrm{ME}$ & reni & & TRIFI068-08 & ME068 \\
\hline A. dalecarlica & Ks Salla & TRIFI080-08 & ME080 & A. wallengreni & Li Utsjoki & TRIFI069-08 & ME069 \\
\hline A. dalecarlica & Li Utsjoki & TRIFI085-08 & ME085 & & Le Enonte & TRIFI007-08 & ME007 \\
\hline A. dalecarlica & Le Enonte & & ME086 & & & TRIFI070-08 & ME070 \\
\hline A. dalecarlica & Ta Ruovesi & TRIFI087-08 & ME087 & & $\mathrm{Li} \mathrm{Ut}$ & TRIFI071-08 & ME071 \\
\hline A. dalecarlica & $\mathrm{Tb}$ & TRIFI088-08 & ME088 & A. 2 & Li Utsjoki & TRIFI072-08 & ME072 \\
\hline A. dalecarlica & Ob Utajärvi & TRIFI090-08 & ME090 & A. zonella & Le Enontekiö & TRIFI073-08 & ME073 \\
\hline A. dalecarlica & Ok Kuhmo & TRIFI092-08 & ME092 & & Le Enontekiö & TRIFI074-08 & ME074 \\
\hline A. dalecarlica & St Jämij & TRIFI093-08 & ME093 & & & TRIFI076-08 & ME076 \\
\hline & N Nummi-Pu & & & & Le Enontekiö & TRIFI077-08 & ME077 \\
\hline carlica & Sb Kuopio & TRIFI095-08 & ME095 & L. rhombicus & Li Inari & TRIFI096-08 & ME096 \\
\hline A. dalecarlica & Li Inari & TRIFI100-08 & ME106 & & & & \\
\hline
\end{tabular}

bootstrap with 1,000 pseudoreplicates, with 5 random addition replicates within each pseudoreplicate.

For the Bayesian inference analysis the dataset was analysed using the program MrBayes 3.1 (Ronquist \& Huelsenbeck 2003). The data were analysed using the GTR $+\Gamma$ model, which was chosen based on AIC score by the program FindModel (available online http://www.hiv.lanl. gov/cgi-bin/findmodel/findmodel.cgi). The analyses were run for 5 million generations with the chain being sampled every 300 generations. The point of convergence was determined visually by plotting the log likelihood of the data against the 
Table 2. Genetic distances of haplotypes sampled within and between species of Finnish Apatania.

\begin{tabular}{lllllllllll}
\hline & dal & aur & for & his & mul & nr.h & sti & wal & zon & zon70 \\
\hline dalecarlica & 0.001 & & & & & & & & & \\
auricula & 0.016 & 0 & & & & & & & & \\
forsslundi & 0.021 & 0.024 & 0.001 & & & & & & & \\
hispida & 0.014 & 0.019 & 0.017 & 0 & & & & & & \\
muliebris & 0.081 & 0.088 & 0.087 & 0.08 & 0.001 & & & & & \\
nr.hispida & 0.014 & 0.019 & 0.017 & 0 & 0.08 & 0 & & & & \\
stigmatella & 0.102 & 0.101 & 0.111 & 0.101 & 0.128 & 0.101 & 0.003 & & & \\
wallengreni & 0.113 & 0.113 & 0.113 & 0.104 & 0.119 & 0.104 & 0.127 & 0.011 & & \\
zonella & 0.017 & 0.022 & 0.021 & 0.017 & 0.087 & 0.017 & 0.104 & 0.117 & 0.002 & \\
zonellaME70 & 0.004 & 0.014 & 0.021 & 0.014 & 0.082 & 0.014 & 0.105 & 0.114 & 0.015 & $N^{*}$ \\
\hline
\end{tabular}

*NA: Not applicable, single specimen.

number of generations and then the "burn-in" period was discarded. The posterior probabilities for clades were summarized through a majority rule consensus tree of the sampled trees.

After getting the verifications on determining the taxa in the DNA tests, hundreds of Finnish samples belonging to the $A$. zonella group were checked morphologically. This additional study was made to see if the conclusions on distribution and larval habitats suggested were supported by a wider material. Based on this material we provide a key to identifying Finnish Apatania based on morphology.

\section{Results}

In total 83 Apatania samples, 9 of which were larvae, were successfully sequenced for the DNAbarcode and they covered all the known Finnish taxa, 8 species and 1 outgroup taxon. Sequence variation within species was close to zero in most species $(0.1$ to $0.3 \%$ pairwise divergence based on Kimura-2-parameter distances, Table 2). The exception is $A$. wallengreni, which had a maximum divergence of $1.1 \%$ (Table 2 ), but this is due to one specimen being very divergent from the other five. The interspecific divergences were much higher. In the closely related zonella group the range was $1.4-2.4 \%$ and in more distantly related species $8-10 \%$ (Table 2).

These divergences are reflected in the NJ tree (Fig. 1), in which individuals of almost all species cluster together to the exclusion of other species. The analysed Finnish Apatania specimens can be divided in to four distinct groups; the $A$. zonella group and the distinct species $A$. stigmatella, $A$. wallengreni and A. muliebris. Within the A. zonella group, the Finnish species consist of well separated A. dalecarlica, A. zonella, A. forsslundi, $A$. auricula and $A$. hispida. Importantly, $A$. zonella and $A$. dalecarlica are as different from each other as they are to the other species in the $A$. zonella group, with the exception of $A$. zonella ME070, which clusters with A. dalecarlica. Also A. nr. hispida, which has earlier been regarded as A. forsslundi by Mattila \& Salokannel (2004), are here identical to $A$. hispida.

The phylogenetic analyses of the data gave identical trees in which the relationships of the species in the $A$. zonella group were unresolved (Fig. 2). Apatania muliebris is a sister species to the $A$. zonella group, with $A$. wallengreni being sister to that clade. Based on this limited sampling of species and DNA sequences, it appears that parthenogenesis has evolved once in the ancestor of the $A$. zonella group $+A$. muliebris.

\section{Discussion}

The DNA barcoding approach is successful for Finnish species of Apatania, with the caveat that the type specimens of Apatania species have not been analysed. Therefore, the connection with correct species names is based on morphological identification. This has been traditionally problematic for the species pair A. zonella and $A$. dalecarlica. The European Atlas of Trichoptera (Malicky 2004) excludes $A$. dalecarlica and it is 


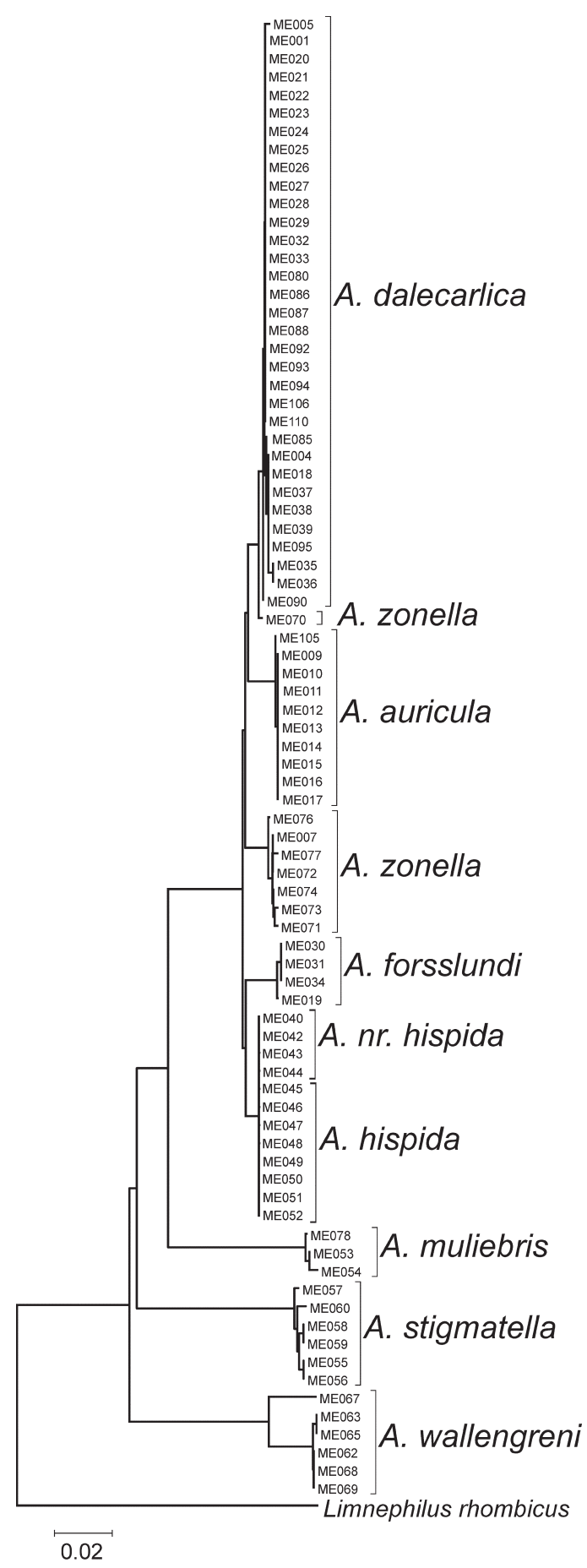

Fig. 1. Neighbour joining tree of partial COI gene sequence of Finnish species of Apatania based on genetic distances calculated with the Kimura-2-parameter model.

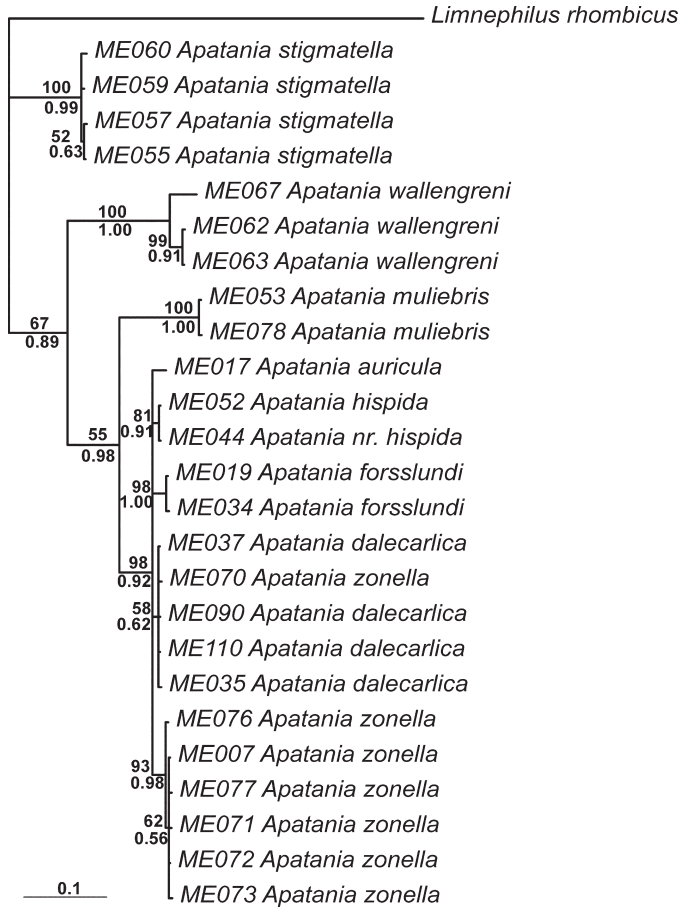

Fig. 2. Phylogenetic relationships of all unique haplotypes of Apatania COI gene sequences based on a Bayesian analysis. Numbers above branches are bootstrap values from a parsimony analysis, numbers below branches are Bayesian posterior probabilities (see text for details).

questionable whether the illustration of the female A. zonella genitalia belongs to A. zonella or A. dalecarlica. Also, A. forsslundi is a rather poorly known taxon and has caused problems together with the two previous taxa (Solem 1985).

Our DNA barcoding results support keeping A. zonella and $A$. dalecarlica as separate species. Morphological identification of the rare males is relatively easy as shown in Schmid (1954). The morphological identification of females seems also normally possible, mainly because of the different shape of segment IX (Fig. 3a and 3e). Finnish specimens also match well with the description in Chuluunbat (2008). The results suggest that $A$. zonella is a northern species in Finland; all the samples of $A$. zonella were collected from subarctic stony lakes and large ponds. Apatania dalecarlica is spread throughout the country, but is rather local, occurring only in stony or sandy springs and other ground water fed brooks. The DNA barcoding results of the A. dalecarlica 

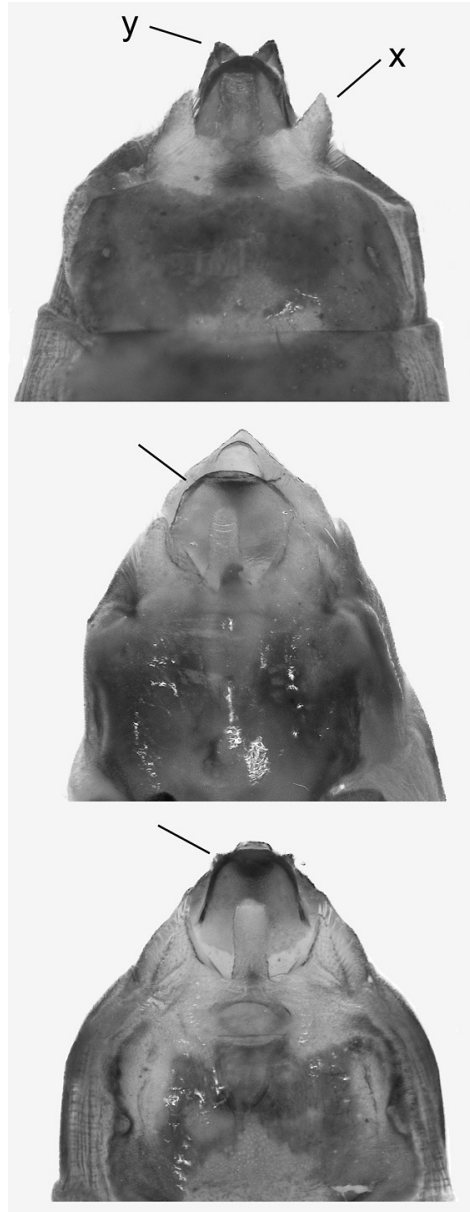

C

e

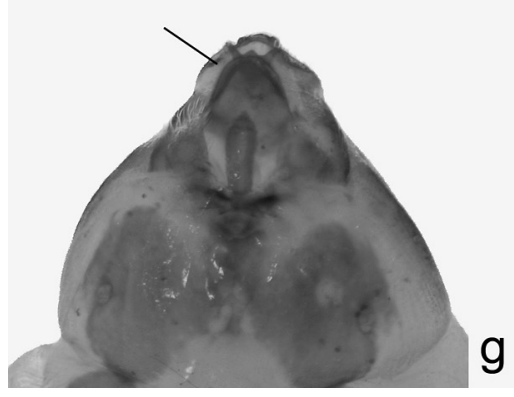

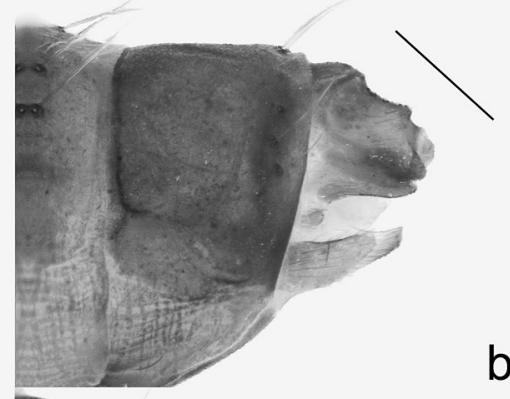

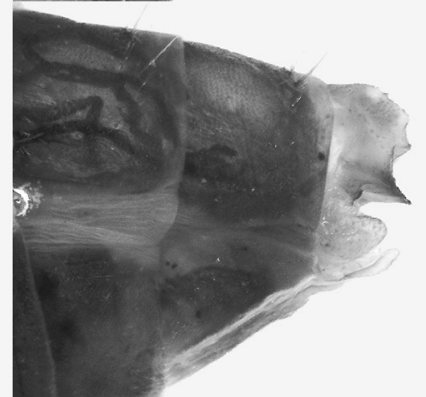

d
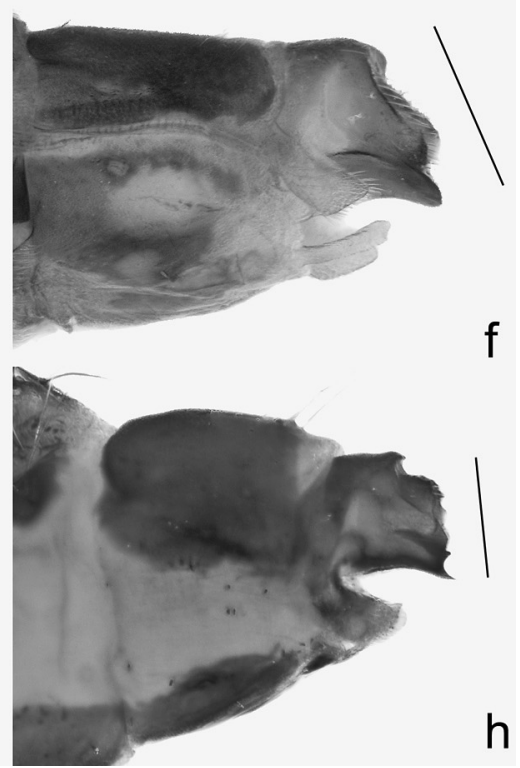

Fig. 3. Apex of female abdomen. - a. A. dalecarlica, ventral view, $\mathrm{x}$ : Latero-basal lobes of segment IX, y: strong apical lobes. - b. A. dalecarlica, lateral view, line: descending profile. -c. A. auricula, ventral view, arrow: blunt shape of supragenital plate. - d. A. auricula, lateral view, line: steep, descending profile. $-\mathrm{e}$. A. zonella, ventral view, arrow: minor apical lobes. - f. A. zonella, lateral view, line: descending profile.

- g. A. forsslundi, ventral view, arrow: triangular shape of supragenital plate. $-\mathrm{h}$. $A$. forsslundi, lateral view, line: steep, descending profile. specimens of northern half of Finland are almost identical, while the southern Finland specimens have more variation. Morphologically analyzed specimens in Finnish collections also conform to this distribution pattern. A single A. zonella (ME070) that clustered with A. dalecarlica is a mystery at the moment. Morphologically the specimen is identical to other $A$. zonella specimens collected in the same place (e.g. ME071 and ME072 in Fig. 1). More data would be required to discover whether this is a case of hybridization, and documenting the extent of the phenomenon would require more specimens of $A$. zonella.

The taxon that has been treated as a variation of $A$. forsslundi by Finnish authors (Mattila \& Salokannel 2004, Fig. 4a-b) seems to be more closely associated with $A$. hispida than $A$. forsslundi. The DNA barcoding results show no difference to $A$. hispida, although the taxon is rather easily separable from $A$. hispida morpho- 

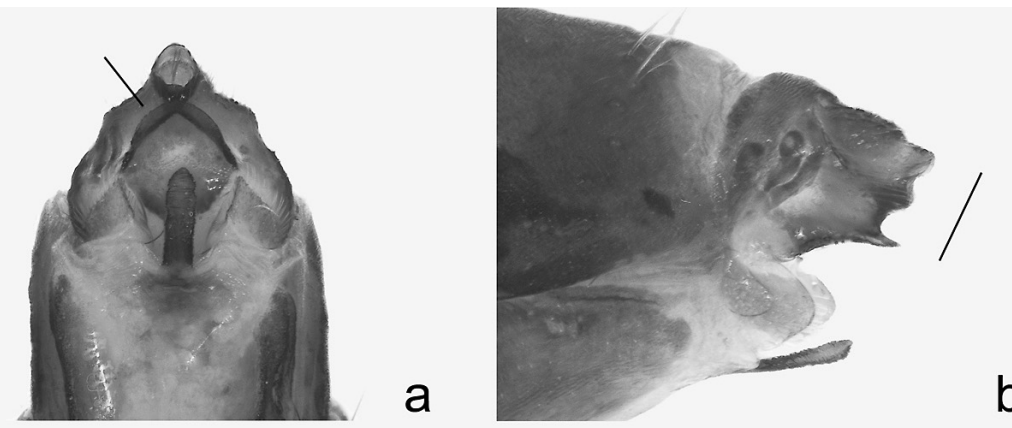

b

Fig. 4. Apex of female abdomen. - a. A. nr. hispida, ventral view, arrow: triangular shape of supragenital plate. - b. A. nr. hispida, lateral view, line: ascending profile. - c. A. hispida, ventral view, arrow: blunt shape of supragenital plate. d. A. hispida, lateral view, line: ascending profile. - e. A. muliebris, ventral view, arrow: small lobes of supragenital plate. f. A. muliebris, lateral view, line: ascending profile. - g. A. stigmatella, ventral view, arrow: Latero-basal lobes of segment IX minor or missing. h. A. stigmatella, lateral view. -i. A. wallengreni, ventral view, arrow: apically pointed tip of abdomen. $-\mathrm{j}$. A. wallengreni, lateral view.

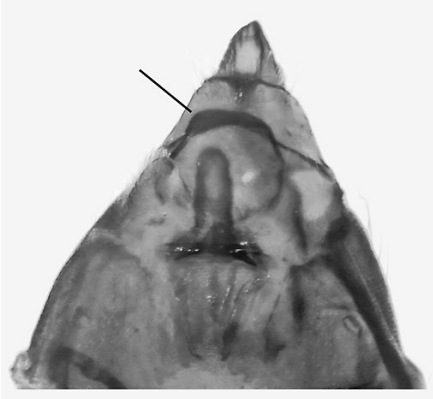

C
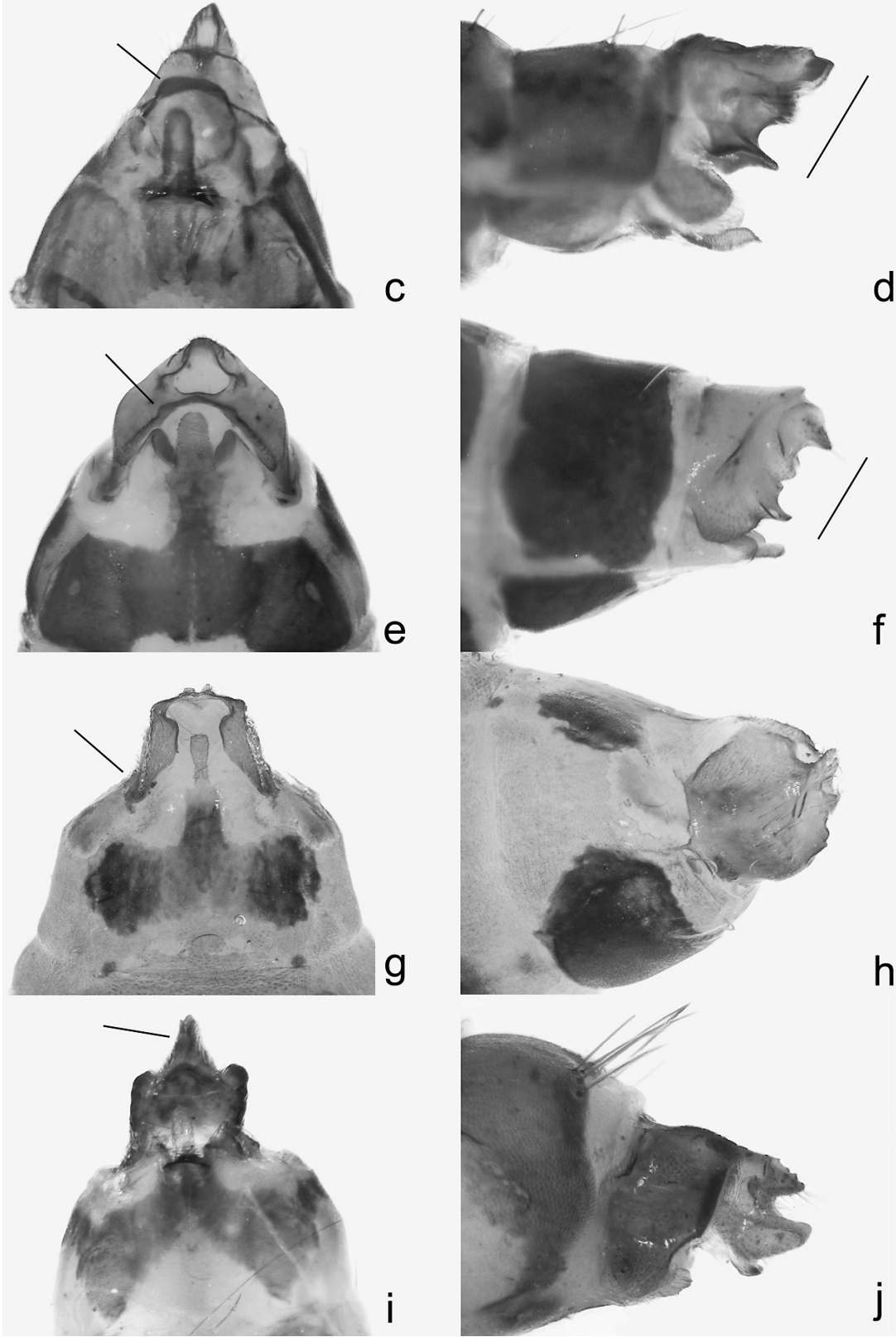
logically. Also, Solem (1985, Fig. 2 A-C) places this form correctly with $A$. hispida. The misassociation with $A$. forsslundi was because the two samples Mattila \& Salokannel (2004) got as reference of $A$. forsslundi from Seckenberg museum, Germany, appeared to be separate taxa, not two forms of $A$. forsslundi. All three taxa: $A$. hispida, $A$. nr. hispida and $A$. forsslundi occur in very cold, ground water fed brooks in Finnish Lapland, sometimes together in the same location. Thus, the taxonomic status of $A$. nr. hispida remains unclear, with the DNA-barcode suggesting that it is not a separate taxon to A. hispida, but morphology and possibly distribution suggesting that it is a separate taxon. A further complication is that both $A$. hispida and A. forsslundi are apparently parthenogenetic species, and thus hybridization is not an option. Apatania nr. hispida may therefore represent a new parthenogenetic lineage that has branched off of $A$. hispida so recently that no mutations have occurred in the DNA-barcode region yet.

The taxon $A$. nr. hispida has apparently attracted the attention of earlier workers on Apatania taxonomy in Finland. We discovered one old specimen in the collection of the Zoological Museum at the University of Turku, Finland, that appears morphologically similar to Apatania nr. hispida, despite being somewhat disfigured by desiccation. This specimen is labelled as "Apatania kaisilai, det. Forsslund". The description of "Apatania kaisilai" was never published making the name unavailable, but the taxon was later included in some publications (Nybom 1960, Malicky 2005). Due to the similarity, we think it is probable that $A$. nr. hispida and the undescribed "A. kaisilai" are the same taxon. If any further material of this taxon determined by Forsslund exists, it would help to verify the naming suggestion and could form the basis of describing the taxon formally.

One of the A. wallengreni samples (ME067), collected from small highland lake in NE Lapland (Li:Utsjoki, 3.7.2007) was quite divergent to the other five specimens of $A$. wallengreni. When analysed with other Apatania sequences in BOLD, this specimen appeared to be closer to Mongolian A. crymophila specimens (S. Chuluunbat and X. Zhou, pers. comm.) than our other Finnish A. wallengreni samples. However, the structures of the last abdominal segments of this (and other specimens from the same collection) are very close to normal $A$. wallengreni, giving only a slight hint towards the shape of $A$. crymophila. The identity of such forms needs more thorough study.

All the larvae included in DNA analysis belong to A. dalecarlica. The larva is not yet described in literature, suggesting that the DNA barcode might be a useful way of identifying undescribed larvae to associated species (see e.g. Johanson 2007).

The morphological analysis of wider Finnish material of A. zonella group supported all the suggestions of DNA analysis related to the distribution and larval habitats: $A$. zonella occurs in stony subarctic lakes and ponds in Lapland, A. auricula in stony lakes and large rapids throughout the country. A. dalecarlica, A. hispida, A. nr. hispida and $A$. forsslundi live in springs and ground water fed sandy or stony brooks. A. dalecarlica occurs throughout the country, while the other spring species are found only in north Finland. Based on morphological features, the Finnish specimens of A. muliebris are interpreted to belong to the subspecies A. muliebris cimbrica (Nielsen).

\section{Key to Finnish Apatania species}

The keys should be used together with the genitalia pictures. Due to variation in morphological features, some specimens may be difficult to determine. The water habitat and the geographical location may give confirming hints.

\subsection{Key to the females of Finnish Apatania species}

1. Latero-basal lobes of segment IX missing or negligible (Figs. 4g and 4h) 2

- Latero-basal lobes of segment IX well developed (Fig. 3a(x))

2. Segment IX without evident lobe on lateral view (Fig. 4h); segment IX apically blunt in ventral view (Fig. 4g). Throughout the country in lakes, rivers and brackish water

A. stigmatella

- Segment IX with evident lobe in lateral view 
Fig. 5. Apex of male abdomen. - a. A. dalecarlica, dorsal view, arrow: long median process. - b. A. dalecarlica, lateral view, arrow: ventral knobs of external branches. - c. A. auricula, dorsal view. - d. $A$. auricula, lateral view, arrow: negligible ventral knobs of external branches. - e. A. zonella, dorsal view, arrow: thick, short median process. -f. A. zonella, lateral view, arrow: ventral knobs of external branches.

- g. A. stigmatella, ventral view, arrow: terminal segments of inferior appendages with a strong hook. - h. A. stigmatella, lateral view, arrow: strong inferior appendages. $-\mathrm{i}$. $A$. wallengreni, ventral view, arrow: terminal segments of inferior appendages without a strong hook. -j. A. wallengreni, lateral view, arrow: strong inferior appendages.
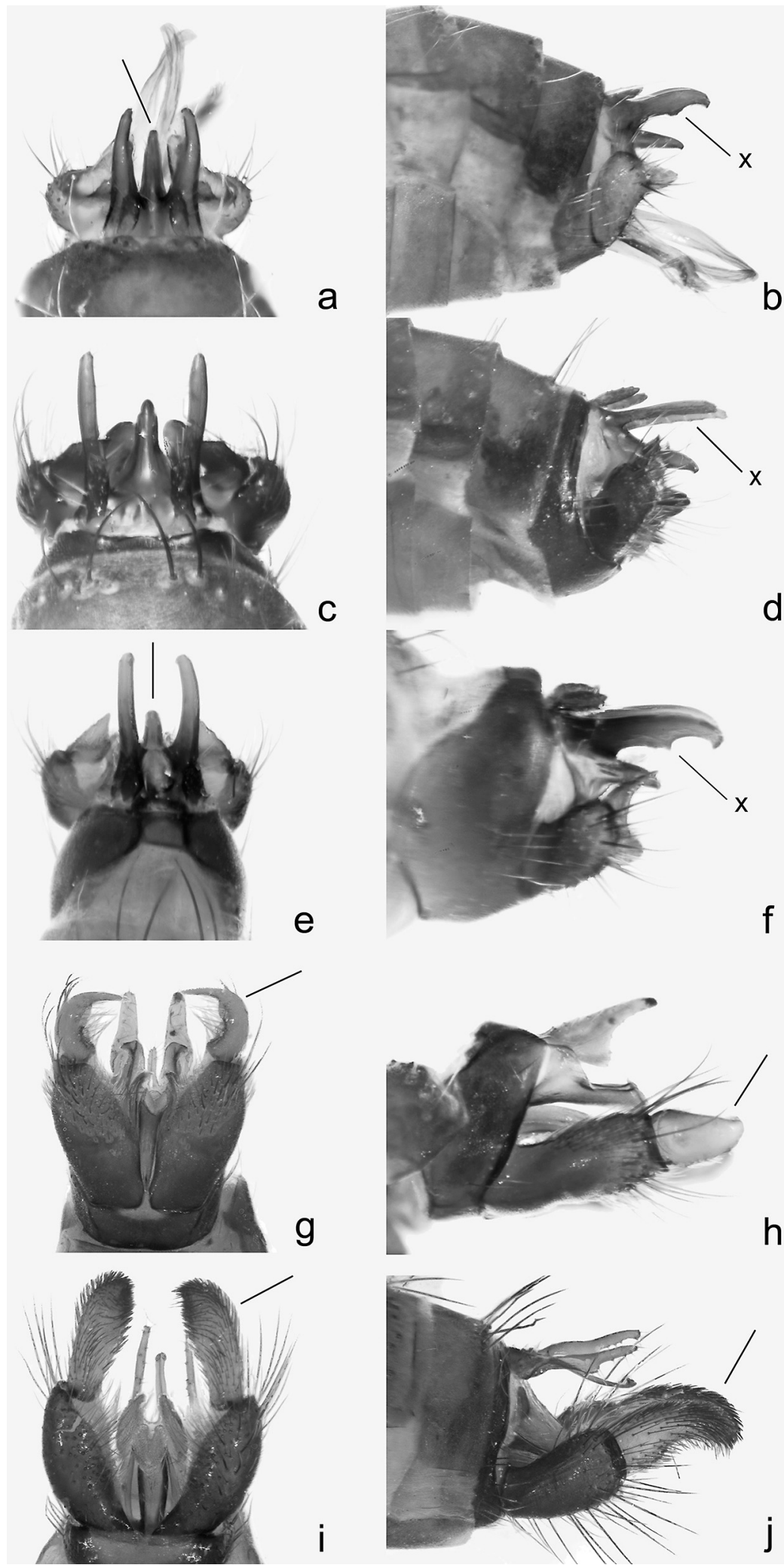
(Fig. 4j); segment IX apically pointed in ventral view (Fig. 4i). Common in north Finland in lakes, rivers and brackish water

\section{A. wallengreni}

3. Lateral profile ascending, the upper part of segment IX reaches beyond the tip of the supragenital plate (Fig. 4b, 4d and 4f)

4

- Lateral profile descending, the upper part of segment IX does not reach beyond the tip of the supragenital plate, or it may do it slightly in the middle (Figs. 3b, 3d, 3f and 3h)

4. Supragenital plate with small sinuation or cutting on the apical corners (Fig. 4e); segment IX with two "teeth" bent towards each other (Fig. 4f). In northern springs

\section{A. muliebris cimbrica}

- Supragenital plate without sinuation or cutting on apical corners

\section{5}

5. In lateral view, the upper part of segment IX reaches apically as far as the tip of the supragenital plate (Fig. 4b); supragenital plate triangular and pointed in ventral view (Fig. 4a). In northern springs $\quad$ A. nr. hispida

- In lateral view the upper part of segment IX reaches far beyond the tip of supragenital plate (Fig. 4d); supragenital plate is blunt (Fig. 4c). In northern springs A. hispida

6. Segment IX relatively narrow on ventral view, often with almost parallel sides; apical lobes usually ventrally strongly visible (Fig. 3a (y)). In springs throughout the country

\section{A. dalecarlica}

- Segment IX more thick, not parallel sides; apical lobes ventrally small or invisible 7

7. Supragenital plate somewhat triangular (Fig. $3 \mathrm{~g}$ ); in lateral view, the tip of the segment IX very steep (Fig. 3h). In northern springs

\section{A.forsslundi}

- Suprageniral plate blunt. In lateral view, the tip of segment IX is either not steep (Fig. 3f) or it is clearly bent inwards above supragenital plate (Fig. 3d)

8. Segment IX relatively shorter and blunter in lateral view (Fig. 3d); apical lobes ventrally practically invisible, supragenital plate shorter (Fig. 3c). In lakes and large rapids throughout the country

A. auricula

- Segment IX relatively longer; apical lobes visible (although small) in ventral view (Fig. $3 \mathrm{e})$; supragenital plate longer. In lakes in north Finland

A. zonella

\subsection{Key to the males of Finnish Apatania species}

Males are known only for five Finnish Apatania species.

1. Inferior appendages very strong and much longer than external branches (Figs. $5 \mathrm{~h}$ and $5 \mathrm{j})$

2

- Inferior appendages about the same length or shorter than external branches (Figs. 5b, 5d and 5f) 3

2. Terminal segments of inferior appendages with a strong hook on ventral (Fig. 5g) and dorsal view

A. stigmatella

- Terminal segments of inferior appendages without a strong hook, slight bents towards each other on the tips (Fig. 5i) A. wallengreni

3. External branches thin for their whole length, ventral knobs negligible (Fig. 5c and d (x))

A. auricula

- External branches thicker, usually with one or more distinct ventral knobs (Fig. 5b (x) and $5 \mathrm{f}$ (x))

4. Median process of segment $X$ thick and blunt and its length about half of the external branches. (Fig. 5e and 5f) A. zonella

- Median process of segment X thinner and longer, usually about $2 / 3$ of the external branch length; external branches are usually apically thinner(Fig. 5a and 5b) A. dalecarlica

The phallus with associated structures can be sometimes strongly protruding, like in Fig. 5a and $5 b$.

Acknowledgements. Keijo Mattila and Mikko Ellmén are thanked for the photographs, Jari Ilmonen, Juhani Itämies, Kari Järventausta, Keijo Mattila, Aki Rinne, Esko Saarela, Jukka Salmela and Jukka Tabell for material contributions, Wolfgang Tobias, Suvdtsetseg Chuluunbat and Xin Zhou for valuable consultance and good discussions on Apatania. We thank Mikko Ellmén for help in the lab. 


\section{References}

Carlsson, B.-G. 1982: Caddisflies (Ins: Trichoptera) in coastal areas of the Gulf of Bothnia. - In: Müller, K. (ed.), Coastal Research in the Gulf of Bothnia: 253262. Dr. W. Junk Publishers.

Chuluunbat, S. 2008: Revision of East Palearctic Apatania (Trichoptera: Apataniidae). - Master of Science thesis. Clemson University, 165 pp.

Elias, M., Hill, R. I., Willmott, K. R., Dasmahapatra, K., Brower, A. V. Z., Mallet, J. \& Jiggins, C. D. 2007: Limited performance of DNA barcoding in a diverse community of tropical butterflies. - Proceedings of the Royal Society Biological Sciences Series B 274: 2881-2889.

Goloboff, P. A. 1998: NONA. - Published by author.

Gullefors, B. 2005: Trichoptera from the brackish water of the Gulf of Bothnia. - Proceedings of the $11^{\text {th }}$ International Symposium on Trichoptera (2003, Osaka). Tokai University Press, Kanagawa. 137-147 pp.

Hall, T. A. 1999: BioEdit: a user-friendly biological sequence alignment editor and analysis program for Windows 95/98/NT. — Nucleic Acids Symposium Series 41: 95-98.

Hebert, P. D. N., Cywinska, A., Ball, S. L. \& deWaard, J. R. 2003: Biological identifications through DNA barcodes. - Proceedings of the Royal Society Biological Sciences Series B 270: 313-322.

Holzenthal, R., Blahnik, R., Prather, A. \& Kjer, K.2007: Order Trichoptera Kirby, 1813 (Insecta), Caddisflies. —Zootaxa 1668: 639-698.

Huelsenbeck, J. P. \& Ronquist, F. R. 2001: MrBayes: Bayesian inference of phylogeny. — Biometrics 17: 754 755.

Ilmonen, J. \& Rinne, A. 2005: Siviäsirvikäs (Apatania muliebris), Suomelle uusi vesiperhoslaji. — Diamina 14: 4-5. [In Finnish.]

Johanson, K. A. 2007: Association and description of males, females and larvae of two New Caledonian Xanthochorema species (Trichoptera: Hydrobiosidae) based on mitochondrial 16S and COI sequences. - Entomological Science 10: 179-199.

Kullberg, J., Albrecht, A., Kaila, L. \& Varis, V. 2002: Checklist of Finnish Lepidoptera. - Sahlbergia 6: 45-190. [Partly in Finnish.]

Kumar, S., Tamura, K. \& Nei, M. 2004: MEGA3: Integra- ted software for Molecular Evolutionary Genetics Analysis and sequence alignment. - Briefings in Bioinformatics 5: 150-163.

Malicky, H. 2004: Atlas of European Trichoptera, Second Edition. - Springer, Dordrecht, The Netherlands.

Malicky, H. 2005: Ein kommentiertes Verzeichnis der Köcherfliegen (Trichoptera) Europas und des Mediterrangebietes. - Linzer Biologische Beiträge 37: 533 596.

Mattila, K. \& Salokannel, J. 2004: Apatania forsslundi Tobias, Suomelle uusi vesiperhonen. — Diamina 13: 4 5. [In Finnish.]

Nielsen, A. 1943: Apatidea auricula Forsslund from a Norwegian Mountain Lake. Description of the imago and Notes on the Biology. - Entomologiske Meddelelser 23: 18-30.

Nixon, K. C. 2002: Winclada. — Published by author.

Nybom, O. 1960: List of Finnish Trichoptera. — Societas pro Fauna et Flora Fennica. Fauna Fennica 6. 1960: 156.

Salokannel, J., Mattila, K., Saarela, E., Bagge, P., Salmela, J. \& Järventausta, K. 2004: Suomen vesiperhosten frekvenssipisteet ja harvinaisten lajien havainnot (Trichoptera). - Sahlbergia 9: 113-121. [In Finnish.]

Schmid, F. 1954: Contribution à l'étude de la sous-famille des Apataniinae (Trichoptera, Limnophilidae). II. Tijdschrift voor Entomologie 97: 1-74.

Silva Brandão, K. L., Lyra, M. L. \& Freitas, A. V. L. 2009 Barcoding Lepidoptera: current situation and perspectives on the usefulness of a contentious technique. Neotropical Entomology 38: 441-451.

Solem, J. 1985: Norwegian Apatania Kolenati (Trichoptera: Limnephilidae): identification of larvae and aspects of their biology in a high-altitude zone. Entomologica Scandinavica 16: 161-174.

Wahlberg, N., Oliveira, R. \& Scott, J. A. 2003: Phylogenetic relationships of Phyciodes butterfly species (Lepidoptera: Nymphalidae): complex mtDNA variation and species delimitations. - Systematic Entomology 28: 257-273.

Wahlberg, N., Weingartner, E., Warren, A. D. \& Nylin, S. 2009: Timing major conflict between mitochondrial and nuclear genes in species relationships of Polygonia butterflies (Nymphalidae: Nymphalini). — BMC Evolutionary Biology 9: 92. 